\section{Kreativ bruk av negative tanker}

Kristian Fjellanger

Feit

Mitt liv som tjukkas. 175 s.

Oslo: Forlaget Manifest, 2010. Pris NOK 269 ISBN 978-82-92866-20-7

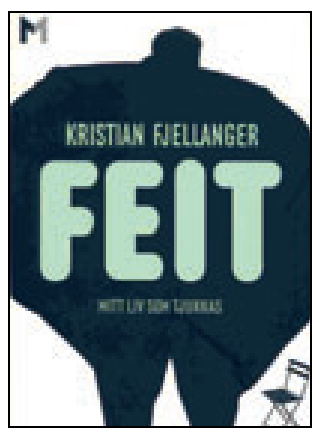

«Speil lyver ikke», skriver Kristian Fjellanger om det året han gikk ned $70 \mathrm{~kg}$ i vekt. Sannhetens øyeblikk kommer da han står foran speilet $i$ et prøverom og gråtende innser at han må kjøpe bukser i størrelse 50. Synet av hans $140 \mathrm{~kg}$ tunge kropp får selvforakten til å velte innover ham - «det feite, late, skitne svinet» - kan han fortjene annet enn forakt fra sine medmennesker? Han erkjenner at han er ulykkelig og frastøtende - ikke rart han ikke får draget på damene slik «A-lagsgutane» får. Nå formulerer han sitt nye prosjekt: Han skal kraftig ned i buksestørrelse, visjonen er (vel?) enkel: å få pule mer!

I prosjektets første fase er det daglig, hard trim - det koster mye for en som ikke har forbrent en ekstraordinær kalori på ti år, som han skriver. Fire ganger opplever han at «heimgymapparatene» knuses. Å benytte treningsstudio er utenkelig, gitt all den avsky han mener de slanke, veltrente der har for feite mennesker.

Kostholdet legges om til knekkebrød og kokte fiskekaker. Alkohol og annen kaloriholdig drikke blir bannlyst. Han studerer de ulike slankeoppleggene markedet tilbyr, og ender opp med mindre fett, mindre sukker og mye, mye mindre mat, faktisk helt i tråd med anbefalingene til Statens ernæringsråd!

Som fastlege blir jeg nysgjerrig på hvor han henter motivasjonen til dette slankeprosjektet fra. Helsevesenet er knapt nevnt, og venner eller familie er mer en byrde enn en støtte. Han velger å stå alene på slagmarken. En rød tråd er hvordan han bevisst bruker negative tanker om seg selv som feit, som motivasjonsfaktor. «Feite folk er dumme og late». Han omtaler seg selv som en «tjukk klovn, en svak, mislykka person med betydelig svekkede muligheter både på kjønnsmarkedet og i arbeidslivet».

Tross sin fedme og alle hans negative tanker om seg selv som feit, er boken humoristisk. Vi værer ingen klinisk depresjon. Han faller ikke for fristelsen til å sette seg selv $i$ en offerrolle og krever ingen medlidenhet. Han har mange gode refleksjoner som utfordrer våre fordommer mot feite mennesker, bare å bruke ordet feit er jo grenseoverskridende for de av oss som tror på egen dannelse. Han har mange gode beskrivelser av sine motstridende følelser rundt egen kropp og andres utsagn om kiloene som renner av ham. Han både ønsker og ønsker ikke kommentarer. Selv de mest velmente utsagnene blir tolket negativt fordi han innerst inne er så var på temaet overvekt - et av de mest skambelagte temaene i det moderne samfunnet. Forfatteren har for øvrig et interessant søkelys på at overvektige menn er doble tapere på dette kvinnedominerte feltet.

Vil jeg anbefale denne boken til mine overvektige pasienter? Svaret er ja dersom de har sans for humor og tåler provoserende utsagn om det å være feit. Svaret er nei for alle dem som signaliserer lav selvfølelse og sterk skamfølelse over sin overvekt. Det hviler et ansvar på den som anbefaler en bok, og det ansvaret må man faktisk være seg bevisst når det gjelder denne boken, særlig siden vi leger beveger oss langt inn på våre medmenneskers mest sårbare områder. Som fagperson vil man derimot ha stort utbytte av å lese denne lettleste boken!

\section{Jannike Reymert}

Bakklandet legekontor

Namsos

\section{Tung lærebok om fedme}

\author{
George A. Bray, Claude Bouchard \\ Handbook of obesity \\ Clinical applications. 3. utg. 659 s, tab, ill. \\ London: Informa Healthcare, 2008. \\ Pris GBP 150 \\ ISBN 978-1-4200-5144-5
}

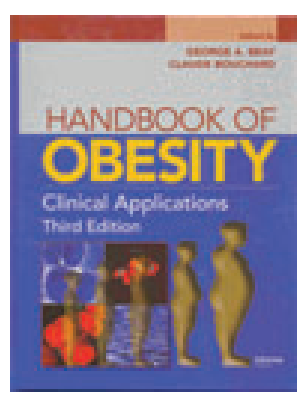

Denne læreboken er beregnet for klinikere og forskere med interesse for fedme. Det er en bokstavelig talt stor og tung bok $(>2 \mathrm{~kg})$ som er meget omfattende og detaljert. Denne anmelderen har

brukt lang tid på å skumme igjennom den. Boken er organisert i fem hovedkapitler som bl.a. omfatter evaluering, utredning, forebygging samt medisinsk og kirurgisk behandling av fedme. Hvert hovedkapittel består av 5-18 mer eller mindre spesifikke temaer, som fedme og allmennpraktikeren, atferdsterapi etc. Mer enn 60 klinikere, epidemiologer og forskere har bidratt til de 40 selvstendige temaartiklene. Handbook of obesity egner seg nok best som en oppslagsbok på kontoret, avdelingen eller i biblioteket.

Det første avsnittet i kapitlet som omhandler evaluering og utredning, er skrevet av Bray selv. Innholdet er leseverdig og kan være nyttig for både norske spesialister og allmennpraktikere. Et annet avsnitt om fedme i allmennpraksis er også godt skrevet, men nok vinklet i sterk grad mot amerikanske forhold. Dette er også et ankepunkt mot andre avsnitt. Forebygging av fedme i et samfunnsperspektiv er diskutert og omtalt på en spennende og god måte.

Kvaliteten på de forskjellige temaoversiktene er ellers varierende, fra meget godt og relevant for norske forhold til for detaljerte eller for overfladiske. Denne vurderingen vil naturligvis variere fra leser til leser og dennes interessefelt og bakgrunnskunnskap. Undertegnede likte spesielt godt kapitlet om medisinsk behandling. Det inneholder imidlertid 18 temaoversikter, der kanskje bare en tredel har interesse for den jevne leser.

Handbook of obesity burde være tilgjengelig på enhver klinisk avdeling med interesse for fedme og fedmerelaterte følgesykdommer.

\section{Jøran Hjelmesæth}

Senter for sykelig overvekt i Helse Sør-Øst Sykehuset i Vestfold

\section{Anmeldelser i Tidsskriftet}

Anmeldelser av bøker og andre medier er en viktig del av Tidsskriftet og skal være til hjelp i avgjørelser om hvilke bøker eller medier som bør anskaffes.

Ta kontakt med redaksjonen på tidsskriftet@legeforeningen.no dersom du har tips om en bok eller annet du mener bør anmeldes eller som du selv ønsker å anmelde. 